\title{
抗体多样性遗传机制发现者一一利根川进
}

郭晓强

解放军白求恩军医学院生化教研室, 石家庄 050081

摘要: 利根川进是一位日本分子生物学家, 由于发现了抗体多样性产生的遗传机制而获得 1987 年诺贝尔生理 学或医学奖; 利根川进还由于研究了学习和记忆的分子与细胞机制而闻名。文章介绍了利根川进的生平和科研 情况。

关键词: 利根川进; 抗体多样性; 遗传机制; 诺贝尔生理学或医学奖

\section{Discoverer of genetic principle for antibody diversity-Susumu Tonegawa}

\section{GUO Xiao-Qiang}

Department of Biochemistry, Bethune Military Medical College, Shijiazhuang 050081, China

\begin{abstract}
Susumu Tonegawa is a Japanese molecular biologist who won the Nobel Prize for Physiology or Medicine in 1987 for his discovery of "the genetic principle for generation of antibody diversity". Susumu Tonegawa is also famous for his important contributions on neuroscience, who explored the molecular and cellular mechanisms underlying learning and memory. In this article, the life and research on Susumu Tonegawa was introduced.
\end{abstract}

Keywords: Susumu Tonegawa; antibody diversity; genetic principle; Nobel Prize for Physiology or Medicine

二十世纪是生命科学取得迅猛发展的时代, 多 个领域均取得巨大进步, 免疫学是其中之一。免疫 学研究的基本问题之一是机体区分“自我”和“非我”, 在外源物质刺激后可启动体液免疫而产生相应抗体, 由于自然界存在着成千上万种物质, 理论上可产生 相应数量的抗体, 但一个物种只有数量有限的编码 基因, 因此 20 世纪 70 年代前, 抗体多样性产生的遗 传机制一直是困扰免疫学界的一大难题。虽提出多 种假说来解释这种现象, 但由于受研究水平所限而 无法得出明确答案。70 年代以后, 随着分子生物学
新技术的不断涌现, 免疫学研究也开始深入到分子 水平, 从而使抗体多样性问题得到了有效解决, 多 位科学家对此做出了重要贡献, 而日本科学家利根 川进(Susumu Tonegawa)的贡献最为突出。

\section{1 学习生物学}

1939 年 9 月 6 日, 利根川进出生于日本的名古 屋市(Nagoya), 父亲利根川勉(Tsutomu Tonegawa)是 日本南部乡村小镇的一家纺织公司工程师。利根川 进的童年就在父亲工作的小镇上度过, 因此对乡村 


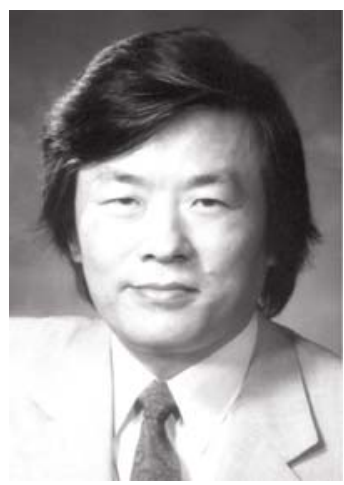

利根川进(来自诺贝尔奖网站 ${ }^{[14]}$ )

(Susumu Tonegawa, 1939-)

的幽雅和自由充满了热爱。利根川进在乡村成长到 上学年龄时, 父母为了让他能接受更好的教育, 将 利根川进和哥哥送到东京姑姑家。利根川进在东京 著名的日比谷高中(Hibiya high school)完成了自己 的高中教育, 期间对化学产生了浓厚的兴趣, 因此 毕业时决定报考著名的京都大学化学系, 尽管第一 年考试失败, 但第二年(1959 年)还是如愿以偿进入 了京都大学。

在大学期间, 利根川进重点学习化学, 理想是 将来做一名化学工程师, 但第二次世界大战失败后 的日本国内生态环境不甚理想，各种争论和斗争使 他感到厌烦, 因此决定改变自己的想法, 将从事学 术研究作为自己的努力方向。即将大学毕业时, 利 根川进恰好阅读到雅各布 (François Jacob)和莫诺 (Jacques Monod)关于操纵子理论的论文, 并深深被这 个理论所吸引, 他决定进入生命科学领域进行研究 ${ }^{[1]}$ 。

1963 年, 利根川进从京都大学毕业并获得化学 学士学位, 随后进入京都大学渡边格(Itaru Watanabe) 教授的病毒实验室打算进行研究生学习, 而渡边格 是当时日本国内少有在美国接受过系统生物学训练 的研究人员之一。但到实验室仅两个月, 渡边格就 和利根川进进行了一次全面的谈话, 告知当时日本 缺乏分子生物学相关方面的系统训练, 如果想在该 领域发展就应该到美国进行深造。当时，日本分子 生物学家发展的基本模式就是在日本获得博士学位 后继续到美国从事博士后研究, 利根川进决定也采 取这种模式。在渡边格教授的建议和实验室同事的 帮助下, 利根川进顺利进入加州大学圣地亚哥分校 生物系林正树(Masaki Hayashi)实验室，在这里利根
川进研究入噬菌体的转录调控机理 ${ }^{[2]}$, 并由于在该方 面的工作而于 1968 年获得博士学位。

毕业后，利根川进在林正树实验室继续进行博 士后研究, 此时重点转向一种新的噬菌体 ØX174 的 形态学观察。然而, 1969 年 4 月, 利根川进转到加州 大学附近索尔克研究所的杜尔贝科(Renato Dulbecco, 1975 年诺贝尔生理学或医学奖获得者)实验室进行 研究。和许多研究者一样, 利根川进当时也认为原 核生物分子生物学黄金期已过，而更大的突破将在 高等生物中取得，但高等生物的复杂性又令科学家 感到气馁, 并且当时也缺乏相应的研究技术, 因此 微小病毒就成为从原核向真核过渡的一座理想桥 梁。杜尔贝科实验室有许多来自世界各地一流的博 士后，他们都已在原核分子生物学方面受到了良好 的培训, 到这里将自己的研究延伸到真核方面, 因 此利根川进在这样的环境中掌握了大量的分子生物 学最新进展。

在杜尔贝科实验室, 利根川进重点研究病毒 SV40(Simian vacuolating virus 40)在细胞内的转录 调节, 通过这些研究一方面对转录调节有了深入认 识, 另一方面也掌握了大量的分子生物学技术。杜 尔贝科实验室是充满自由和上进氛围的地方, 因此 利根川进决定在这里进行更深入的研究, 但不幸的 是利根川进在美国的签证于 1970 年底即将到期, 而 当时获得再次签证至少需要两年时间, 这就意味着 在此期间利根川进将无法待在美国。尽管利根川进 已经在世界其他地方获得了两三份工作，但对这些 工作都缺乏足够兴趣。就在利根川进无法确定自己 下一步计划时, 1970 年秋他收到一封杜尔贝科来信, 杜尔贝科当时正在欧洲旅行，在信中提及瑞士新建 的巴塞尔免疫研究所并建议利根川进可尝试利用分 子生物学进行免疫学问题的研究。利根川进尽管当 时对免疫学一知半解, 但决定接受杜尔贝科建议, 向巴塞尔免疫研究所所长、著名免疫学家杰尼(Niels Kaj Jerne, 1984 年诺贝尔生理学或医学奖获得者)提 出了申请, 幸运的是他被研究所接收并签署了两年 合同。

\section{2 抗体多样性产生遗传机制的发现}

1971 年 2 月, 利根川进开始了在巴塞尔免疫研 究所的工作。利根川进发现周围的环境发生了极大 
变化, 同事们不再是分子生物学的研究人员, 而是 免疫学方面的专家, 他钟情的 SV40 研究已无法与 他人有效的交流，因此第一年在艰难的状况下度 过。利根川进后来敏锐意识到如果想与周围的同事 进行沟通并从他们那里获益, 唯一的途径是将自己 的研究转移到免疫学, 从中寻找自己感兴趣的课题。

1971 年底, 利根川进获悉当时免疫学的最大难 题之一是抗体多样性的遗传起因。科学家提出了两 种解释理论: 一是生殖系理论, 认为所有抗体都有 专一基因负责, 该理论的问题在于面对如此众多的 抗体生物体内基因数目无法满足; 二是体细胞突变 理论, 认为抗体基因可以发生突变和重组, 该理论 能够解释很少基因数目可产生大量微小差异的抗 体。两个理论之间有着激烈争论, 但都缺乏相关的 实验支持。利根川进相信凭借自己的分子生物学基 础并应用当时新发明的技术一一限制酶酶切和重组 DNA 等能够解决这个难题。

利根川进首先纯化了抗体的mRNA，然后将其 与DNA杂交并进行观察，这个实验可有效计算抗体 的基因数目, 结果表明远远少于抗体数目, 因此否 定了生殖系理论。利根川进随后对抗体基因的表达 进行了深入系统的研究, 他的周围也形成了一个高 效的研究小组, 并且研究所主任杰尼很快就意识到 该工作的重要性, 对他进行强有力的支持, 这些因 素大大加快了研究的进程。但是, 当时Southern分子 杂交技术尚末发明, 因此DNA杂交实验是一件非常 繁重的工作。首先需要用限制性内切酶对基因组 DNA进行消化, 然后利用大规模凝胶琼脂糖电泳进 行分离, 将包含特定条带的凝胶进行回收并在液相 反应体系中进行DNA杂交。此外，由于切口平移 (Nick-translation)和cDNA克隆技术均尚未发明，因 此杂交探针使用的抗体轻链mRNA不得不首先从细 胞中纯化, 然后用放射性碘元素标记。利根川进就 是在这种情况下取得了一系列重大突破 ${ }^{[3]}$ 。结果发 现来自非产生 Ig的胚胎细胞和产生 Ig的骨髓瘤细胞 的杂交模式显著不同。

1976 年, 利根川进和同事比较胚胎细胞 $($ 不产 生抗体)和骨髓瘤细胞(产生抗体)中抗体轻链基因的 分布情况时发现在胚胎期不同抗体基因的距离较远, 而在骨髓瘤细胞中这些基因距离靠近, 这个设计精 密且令人信服的实验说明生殖细胞在发育成 $\mathrm{B}$ 淋巴
细胞的过程中, 抗体基因出现了重分布现象 ${ }^{[4]}$ 。利根 川进在此基础上对抗体基因的重分布现象及机制进 行了全面研究，从1976 年到 1981 年的 5 年中用一系 列坚实的证据确定了体细胞突变理论的正确性 ${ }^{[5-7]}$, 即 抗体多样性是由于 $\mathrm{B}$ 淋巴细胞中抗体基因片段的染 色体重组和突变所造成 ${ }^{[8]}$ 。根据估算抗体基因通过 DNA重组和突变可以产生 100 亿种不同抗体, 因此 很好解释了多样性问题。

利根川进抗体多样性遗传机理的阐明对免疫学 的发展具有十分重要的意义, 预示着进入了分子免 疫学时期, 这项发现还改变了人们对基因的传统看 法, 即一个基因编码一种蛋白, 发育和细胞分化过 程中不发生变化。1987 年, 利根川进由于“抗体多样 性产生遗传机理的发现”而独享了该年度的诺贝尔 生理学或医学奖。利根川进获奖名望所归, 但独享 该项大奖则使科学界感到意外, 因为另外两位科学 家哈佛大学的里德(Philip Leder)和加州理工学院的 胡德 (Lerov Hood $)^{[9]}$ 也在该领域做出了卓越贡献 (三 人由于在抗体多样性机理阐明方面的贡献而分享 1987 年拉斯克基础医学奖)。

\section{3 神经生物学研究}

80 年代早期, 利根川进感觉到抗体多样性的问 题已基本解决，因此考虑改变研究环境能够重新开 始新研究。1981 年, 利根川进在麻省理工学院癌症 研究中心获得了一个新位置, 该中心主任是著名分 子生物学大师卢里亚(Salvador Luria, 1969 年诺贝尔 生理学或医学奖获得者), 他不仅将利根川进带入麻 省理工, 而且还提供了设备完备的实验室为开展研 究奠定了基础, 利根川进成功的一个关键因素是一 生得到多位科学大师的帮助。

在麻省理工学院, 利根川进早期研究主要关注 两个问题, 一是研究体细胞重组在抗体基因激活方 面的作用, 另一方面扩展到研究免疫系统的另一半, 即 $\mathrm{T}$ 细胞的抗原受体。利根川进和同事研究发现抗体 重链基因的转录需要组织特异性增强子, 鉴定、克 隆并测定了 $\mathrm{T}$ 细胞受体 $\alpha$ 亚基的基因 ${ }^{[10]}$ ，此外还发现 一个 $\mathrm{T}$ 细胞受体新亚基 $-\gamma$ 亚基，这些知识对理解 $\mathrm{T}$ 细胞介导的免疫系统工作机理具有十分重要的意 义。

进入 90 年代, 利根川进研究兴趣转移到了一个 
全新领域——神经生物学。利根川进在抗体研究中 已开始使用基因敲除小鼠，而现在利用这种技术进 行了小鼠的学习和记忆的研究。利根川进还改进了 基因敲除技术，能够使特定基因在成年动物大脑特 定区域关闭，事实证明这种方法对研究神经功能具 有十分重要的意义。1992 年, 利根川进和同事利用 基因敲除小鼠第一次鉴定了与学习能力相关的基因, 即 $\alpha$-钙离子/钙调素依赖的激酶 II (alpha-calciumcalmodulin-dependent kinase II, alpha-CaMKII), 敲 除小鼠表现出空间学习能力受损的表型 ${ }^{[11]}$, 这对全 面理解大脑功能所有基因研究走出了第一步。在随 后十几年的研究中, 利根川进和同事借助小鼠模型, 充分利用多学科方法包括分子和细胞生物学、体内 和体外电生理学、行为学等鉴定出多种与学习和记 忆有关的基因，并且还发现这些基因与特定疾病有 密切联系, 如精神分裂症、Alzheimer病和痴呆等相 关动物模型都已经制备成功。1996 年, 利根川进和 同事利用条件敲除技术使小鼠海马CA1 区域的N-甲 基-D-天冬氨酸受体 1(N-methyl-D-aspartate receptor 1, NMDAR1)缺失，小鼠的空间记忆能力丧失 ${ }^{[12]} ; 2001$ 年，利根川进小组又进一步发现大脑皮质中 $\mathrm{N}$-甲基 -D-天冬氨酸受体基因在神经细胞交流和长期记忆 追忆过程中发挥着重要作用 ${ }^{[13]}$ ，因为小鼠大脑海马 区的该基因缺陷后虽然长期记忆仍然可形成，但追 忆过程则需要更多线索提示。

\section{4 重大科学贡献}

利根川进担任麻省理工神经生物学教授以及 Picower学习和记忆研究所所长, 目前还是日本理化 研究所-麻省理工学院神经环路遗传学中心主任, 日 本理化研究所脑科学研究所中心主任, 1988 年起还 担任霍华德休斯医学研究所的研究员(2009年退休)。 利根川进是美国科学院外籍院士(保留日本国籍)和美 国艺术与科学学院院士。除获得诺贝尔奖和拉斯克 奖外, 利根川进还获得许多重要的科学大奖, 如美 国哥伦比亚大学授予的Louisa Gross Horwitz奖(1982 年)、加拿大授予的Gairdner基金会奖(1983 年)和德 国授予的罗伯特科赫奖(1986 年)等 ${ }^{[14]}$ 。

利根川进是 20 世纪唯一一位拥有亚洲国籍的 诺贝尔生理学或医学奖获得者, 在抗体多样性和神 经生物学方面的贡献使他成为生命科学领域著名的
科学大师之一。

\section{参考文献(References):}

[1] Shampo MA, Kyle RA, Steensma DP. Susumu Tonegawa-Japan's first Nobel laureate in physiology or medicine. Mayo Clin Proc, 2011, 86(2): e14.DOI

[2] Tonegawa S, Hayashi M. Genetic transcription directed by the b2 region of lambda bacteriophage. Proc Natl Acad Sci USA, 1968, 61(4): 1320-1327. DOI

[3] Hozumi N, Tonegawa S. Evidence for somatic rearrangement of immunoglobulin genes coding for variable and constant regions. Proc Natl Acad Sci USA, 1976, 73(10): 3628-3632. DOI

[4] Tonegawa S. That great time in Basel. Cell, 2004, 116(2 Suppl): S99-S101. DOI

[5] Brack C, Hirama M, Lenhard-Schuller R, Tonegawa S. A complete immunoglobulin gene is created by somatic recombination. Cell, 1978, 15(1): 1-14. DOI

[6] Bernard O, Hozumi N, Tonegawa S. Sequences of mouse immunoglobulin light chain genes before and after somatic changes. Cell, 1978, 15(4): 1133-1144. DOI

[7] Lenhard-Schuller R, Hohn B, Brack C, Hirama M, Tonegawa $\mathrm{S}$. DNA clones containing mouse immunoglobulin kappa chain genes isolated by in vitro packaging into phage lambda coats. Proc Natl Acad Sci USA, 1978, 75(10): 4709-4713. DOI

[8] Tonegawa S. Somatic generation of antibody diversity. Nature, 1983, 302(5909): 575-581. DOI

[9] 郭晓强. 自动测序仪的发明者一记科学家胡德. 生物 学通报, 2005, 40(6): 58-59. DOI

[10] Hayday AC, Diamond DJ, Tanigawa G, Heilig JS, Folsom V, Saito H, Tonegawa S. Unusual organization and diversity of T-cell receptor a-chain genes. Nature, 1985, 316(6031): 828-832. DOI

[11] Silva AJ, Paylor R, Wehner JM, Tonegawa S. Impaired spatial learning in alpha-calcium-calmodulin kinase II mutant mice. Science, 1992, 257(5067): 206-211. DOI

[12] Tsien JZ, Huerta PT, Tonegawa S. The essential role of hippocampal CA1 NMDA receptor-dependent synaptic plasticity in spatial memory. Cell, 1996, 87(7): 13271338. DOI

[13] Iwasato T, Datwani A, Wolf AM, Nishiyama H, Taguchi Y, Tonegawa S, Knöpfel T, Erzurumlu RS, Itohara S. Cortexrestricted disruption of NMDAR1 impairs neuronal patterns in the barrel cortex. Nature, 2000, 406(6797): 726-731. DOI

[14] http://www.nobelprize.org/nobel_prizes/medicine/laureate 
s/1987/tonegawa.html. 